GALEGUISMO, FRANQUISMO

E SALAZARISMO.

A COLONIA E OS INTELECTUAIS

GALEGOS EN PORTUGAL

DURANTE A GUERRA CIVIL

ESPAÑOLA

Alberto Pena Rodríguez

Universidade de Vigo 



\section{BREVE INTRODUCIÓN}

Este texto pretende achegarse a aspectos pouco coñecidos sobre o intercambio ideolóxico entre o franquismo e o salazarismo durante a Guerra Civil española, colocando como pano de fondo o papel do galeguismo e a relación simbólica de Galicia e dos galegos co Portugal salazarista. A afinidade cultural e a fraternidade histórica que uniu a Portugal e a comunidade galega foron utilizadas polo franquismo para favorecer a identificación da sociedade portuguesa e do salazarismo cos seus valores políticos ${ }^{1}$.

Logo da aprobación da Constitución Política en 1933, o chamado Estado Novo, de estrutura corporativa e inspiración fascista, atopábase en fase de consolidación cando se produciu o golpe militar contra a II República española. António de Oliveira Salazar, consciente do perigo que representaba para a estabilidade do seu goberno un réxime político democrático en España, prefería para o país veciño un modelo de Estado que favorecese as sinerxías ideolóxicas. Pretendía que as relacións ibéricas se edificasen sobre unha nova arquitectura institucional, dentro dun marco de relación entre gobernos autoritarios. O modelo republicano español era unha fonte potencial de conflitos internos para Salazar, pois alimentaba a inspiración do movemento republicano portugués. De feito, o goberno republicano español chegara a apoiar incluso os exiliados políticos portugueses para restaurar a democracia en territorio luso ${ }^{2}$.

Entre os intelectuais galegos que axudaron a forxar o molde ideolóxico das novas relacións ibéricas e fomentaron o intercambio franco-salazarista estaban Wenceslao Fernández Flórez, Julio Camba, Álvaro de las Casas ou Eugenio Montes. Estes escritores contribuíron a crear unha imaxe benevolente do Movemento Nacional fascista por medio de diversas intervencións en conferencias, foros de debate ou colaboracións coa prensa portuguesa, dentro dunha orquestrada campaña de propaganda coordinada por axentes franquistas en Portugal, que actuaron co apoio das autoridades lusas durante a Guerra Civil española. O principal artífice das campañas franquistas en Portugal era Nicolás Franco, irmán

Léase Castelao, Alfonso Daniel Rodríguez, Sempre en Galiza, Vigo, Galaxia, 2004.

2 Cf. Oliveira, César, Portugal e a II República de Espanha, 1931-1936, Lisboa, Perspectivas e Realidades, 1985. 
do caudillo español, que se convertería no seu embaixador oficial en territorio portugués a partir de 1938. Nicolás Franco mantivo estreitas relacións cos medios de comunicación lusos, co Secretariado de Propaganda Nacional (SPN) salazarista e con diversas institucións nacionais e internacionais, para crear unha imaxe internacional benevolente do franquismo, especialmente entre os integrantes da colonia galega en Portugal $^{3}$.

\section{A COLONIA ESPAÑOLA E GALEGA EN PORTUGAL NOS TEMPOS DA REPÚBLICA E DA GUERRA}

A colonia española en Portugal tivo historicamente unha relevancia superior a calquera dos colectivos de estranxeiros alí establecidos ${ }^{4}$. A proximidade co país de orixe e a facilidade para integrárense na hospitalaria sociedade portuguesa representaban para os inmigrantes españois vantaxes decisivas para preferir este destino, mentres os cidadáns doutros países que se estableceron en Portugal durante os séculos XIX e XX estaban relegados en pequenos núcleos con menor influencia social e económica. O censo de poboación de 1900 contabilizou 27029 españois, cifra que se reduciu ata os 13092 en 1930, nun declive numérico progresivo que chega ata a actualidade. Quizais debido ao desenvolvemento industrial experimentado en España na década dos anos vinte, desacelerouse o fluxo migratorio da poboación española. Aos emigrantes españois as cidades portuguesas xa non lles resultaban tan atractivas polas penurias da

3 Cf. Pena Rodríguez, Alberto, El gran aliado de Franco. Portugal y la Guerra Civil española: prensa, radio, cine y propaganda, Sada (A Coruña), Ediciós do Castro, 1998.

4 Sobre a inmigración española en Portugal neste período, véxase: Burgos Madroñero, Manuel, «Actividades da colónia e das autoridades diplomáticas espanholas em Portugal», dentro do capítulo titulado «Vinte mil portugueses lutaram na Guerra Civil de Espanha (1936-1939)", Boletim do Arquivo Histórico Militar, vol. 55, pp. 5-227. Do mesmo autor tamén: «As actividades da colónia espanhola em Portugal (1936-1939)», baseado nun estudo inédito máis extenso depositado no Instituto Cervantes de Lisboa, titulado: «La colonia española en Portugal (1900-1982) y el Instituto Español en Lisboa (1932-1982)», Diário de Notícias, 06/07/1986, pp. 15-17; e «La Colonia Española en Portugal y la Guerra Civil (1936-1939)», revista Historia 16, ano XV, n. ${ }^{\circ}$ 172, agosto de 1990, pp. 12-22. De César Oliveira pode lerse: «A colónia espanhola em Portugal. As dúas embaixadas: a republicana e a Embaixada Negra. A Falange Espanhola em Portugal. O processo de ruptura de relações entre Portugal e a República de Espanha», capítulo do seu libro Salazar e a Guerra Civil de Espanha, Lisboa, Edições O Jornal, 2a edición, 1988, pp. 171-201. 
crise económica portuguesa, que se agudizou no período republicano (1910 e 1926) a causa da endémica inestabilidade política do país veciño ${ }^{5}$. Neste período, América convértese no horizonte migratorio máis desexado para españois e portugueses ${ }^{6}$.

Entre a comunidade de inmigrantes españois en Portugal, Galicia era entón unha das maiores exportadoras de capital humano de España e o colectivo rexional máis importante en Portugal. Entre 1911 e 1970, abandonaron a súa terra natal 1900000 galegos $^{7}$. Case todos eles emprenderon rumbo a América, persuadidos nalgúns casos pola propaganda da prensa galega, na que os principais investidores publicitarios eran os consignatarios de buques e armadores, que estimularon a emigración a aquel continente a principios do século $\mathrm{XX}^{8}$.

A instauración da II República en España incrementou notablemente o fluxo migratorio dos españois cara a Portugal entre abril de 1931 e 1934, moitos deles asumindo a condición de exiliados políticos, a maioría procedentes da aristocracia e da alta burguesía madrileña. En 1932, establecéronse en Portugal ao redor de 2000 españois que rexeitaban o novo sistema político e que viron definitivamente frustrados os seus desexos de reinstauración dun réxime conservador co fracasado golpe militar do xeneral Sanjurjo en agosto daquel ano ${ }^{9}$. En xullo de 1936, a colonia española roldaba as 15000 persoas, o $60 \%$ das cales eran de orixe galaica, a maioría de Ourense e Pontevedra, o $15 \%$ eran procedentes de Salamanca e Zamora, e o continxente restante procedía de diversas provincias, entre as que destacaban Badaxoz, Sevilla e Madrid ${ }^{10}$. Algún autor eleva a porcentaxe de galegos ata o $90 \%$, cuxa preponderancia, ademais, está patente no signo galeguista das dúas únicas asociacións rexionais dentro da colonia, a Asociación Galaica de Socorros Mutuos e La Juventud de Galicia. Máis da metade (9500) residían en Lisboa, 1500 vivían en Porto e

5 Pereira, Miriam Halpern, Política y economía. Portugal en los siglos XIX y XX, Barcelona, Ariel, 1984, pp. 184-199.

6 Oliveira, Salazar, pp. 172-173.

7 López Taboada, Xosé Antón, Economía e población en Galicia, A Coruña, Editorial Rueiro, 1979, p. 71.

8 Luca de Tena, Gustavo, Noticias de América. O relato da grande emigración americana na prensa da Galicia de ultramar, Vigo, Nigra, 1993.

9 Oliveira, Salazar, pp. 174 e 175.

10 Burgos Madroñero, Manuel, «As actividades da colónia espanhola em Portugal (1936-1939)», Diário de Notícias, 06/07/1986, p. 15. 
varios miles máis esparexíanse polas outras cidades e localidades portuguesas ${ }^{11}$. Segundo o informe elaborado pola Falange Española Tradicionalista y de las JONS (FET-JONS) en Portugal o 8 de setembro de 1938, os núcleos de españois máis importantes repartidos polas capitais de provincia eran os seguintes: Viana do Castelo: 186, Braga: 163, Bragança: 204, Vila Real de Santo António: 134, Porto: 1210, Guarda: 109, Viseu: 82, Aveiro: 91, Coimbra: 180, Leiria: 108, Setúbal: 377, Santarém: 100, Castelo Branco: 101, Évora: 352, Portalegre: 311, Beja: 394 e Faro: $383^{12}$.

A maioría dos membros da colonia eran obreiros e pequenos industriais que traballaban como camareiros ou donos de hoteis, restaurantes, cafés, tabernas ou pensións, ou que gañaban a vida con oficios como carboeiros ou afiadores ambulantes. Outro grupo integrábano comerciantes que se dedicaban a diversos negocios: axentes de seguros, tendas de paquetarías, tecidos, camisarías, etc. «[...] Este núcleo es el de las mayores aportaciones a suscripciones de todas clases para la España Nacional; personas ya mayores, no envenenadas por el virus marxista que tan intensamente se extendió por España en los últimos años y del que ellos se libraron por su formación anterior a todo esto y por sus largos años de residencia en Portugal y que contribuyen generosamente a todo llamamiento", exponse no citado documento ${ }^{13}$. E o terceiro grupo estaba formado polos funcionarios que traballaban para o Estado español na embaixada, o consulado ou o Instituto Español ${ }^{14}$.

Grazas ás informacións publicadas polo xornal O Século, que dedicou senllas reportaxes especiais á colonia española en Lisboa e Porto, coñecemos máis detalles específicos das actividades económicas desenvolvidas polos españois no

11 Oliveira, Salazar, pp. 173-174.

12 Este informe xa foi citado por César Oliveira, aínda que sen dar unha data precisa sobre a súa elaboración. O informe referido, de 10 páxinas, titúlase «Notas sobre la colonia española de Lisboa». Foi elaborado anonimamente por un membro da Falange Española en Portugal, que o remitiu ao Servicio de Información y Policía Militar do goberno de Burgos, denunciando a actitude indiferente dos representantes rebeldes con relación á Falange. De forma desagregada, contén datos sobre a organización social e as actividades industriais dos españois en Portugal, así como outros aspectos interesantes relacionados co funcionamento dalgúns organismos da colonia e o recrutamento de mozos para o exército franquista. AMAE, R-1058, expediente n. ${ }^{\circ}$ 6. Informe remitido anonimamente o 08/09/1938 ao Servicio de Informaciones Políticas y Militares.

13 Ibidem.

${ }^{14}$ Ibidem. 
seu exilio lusitano e algúns datos interesantes sobre a súa reacción ante a Guerra Civil española (1936-1939) ${ }^{15}$. O Século informaba en abril de 1938 que a colonia española en Lisboa respectaba escrupulosamente as doutrinas da «Nova Espanha», comprometidas co «sentimento do dever» imposto pola FET y de las $\mathrm{JONS}^{16}$. Na capital portuguesa, entre as empresas españolas máis importantes a principios dos anos trinta estaban o vendedor por xunto de froitas Francisco Benito \& C. a , a compañía de seguros España S.A., a exportadora de viños A Nova Sociedade Vinícola, a empresa de transportes Agencia Internacional Aduaneira, de Manuel B. Vivas, os enxeñeiros industriais Durán García \& C. ${ }^{a}$, a céntrica camisaría da Praça do Rossio de Refojos Rodríguez, a Camisaria Moderna, as importadoras madeireiras Torrens \& Marques Pinto e Francisco González y González, o Hotel Universo, a Sapataria Orion, o importador de tabaco Apolinar Contreras, etc. ${ }^{17}$. En Porto, onde vivían arredor de 1500 españois, boa parte da industria téxtil e de curtidos de peles estaba nas súas mans: a Fábrica de Cortumes da Póvoa-Pablo Gati, a Fábrica de Cortumes Rio Leça, La Catalana e a fábrica de Dionisio Mateu, entre outras. Os españois tamén eran propietarios da fábrica de chocolates La Española, das empresas de recauchutados Vulcania e Vulcanoff, e dalgúns comercios relacionados coa hostalaría ${ }^{18}$. Moitas delas fixeron xenerosas doazóns ao exército franquista durante o conflito civil en España. Como curiosidade, a fábrica téxtil de Porto Bosch \& Bayllina, propiedade do delegado da Falange naquela cidade, Ramón Bayllina, doou a produción de calcetíns que tiveron tres das súas máquinas durante toda a guerra ${ }^{19}$.

\footnotetext{
15 Véxase o artigo xornalístico: «A colonia espanhola de Lisboa que acompanha com o maior entusiasmo e patriotismo o movimento nacionalista do generalissimo Franco, está integrada nos principios renovadores da revolução Nacional salvadora da sua gloriosa Pátria», O Século, n. ${ }^{\circ}$ 20151, 24/04/1938, pp. 9 e 10. E tamén: «Movimento Nacionalista de Espanha. A colonia do Porto tem prestado, abnegadamente, o seu valioso auxílio áqueles que se batem no campo de batalha com o alto significado de redimir a Pátria», O Século, n. ${ }^{\circ} 20075,06 / 02 / 1938$, p. 13.

16 O Século, n.o 20151, 24/04/1938, p. 9.

17 Ídem, pp. 9 e 10.

18 Ídem, n. ${ }^{\circ} 20075,06 / 02 / 1938$, p. 13.

19 Ídem, n. ${ }^{\circ} 20067,28 / 01 / 1938$, p. 2.
} 


\section{AS CAMPAÑAS FRANQUISTAS DAS ASOCIACIÓNS DE INMIGRANTES GALEGOS}

A asociación La Juventud de Galicia foi unha das institucións da colonia española máis solidarias co bando franquista. Organizou varias campañas de propaganda para recadar fondos na colonia cos que axudar os militares sublevados. A finais de 1936, por exemplo, organizou unha colecta para enviar o aguinaldo aos soldados de Franco, «[...] que derraman su sangre generosa en el suelo sacrosanto de la Patria». Esta campaña de Nadal foi desenvolvida en colaboración co xornal vigués El Pueblo Gallego, que ofreceu as súas páxinas para facer propaganda franquista e a sede da delegación en Lisboa, situada na Avenida 24 de Julho, como oficina para o depósito dos donativos. Nas súas columnas publicábanse os nomes de todos aqueles que respondían á chamada de La Juventud de Galicia achegando fondos para o exército insurrecto ${ }^{20}$. Esta institución foi tamén protagonista do envío dunha caravana de víveres e material sanitario para o bando franquista de Vigo. O 11 de xaneiro de 1937 transportou duascentas camas e alimentos diversos ${ }^{21}$. Mentres durou a guerra, durante a época de Nadal coordinaba unha campaña de recadación de doazóns para os insurxentes.

De acordo coas instrucións da Representación da Junta de Burgos en Lisboa, organizáronse accións de propaganda nas que colaboraban, ademais da La Juventud de Galicia, a Asociación Galaica de Socorros Mutuos. Esta institución chegou a coordinar directamente con Nicolás Franco a estratexia propagandística que debía seguir o franquismo para persuadir os inmigrantes galegos en $1938^{22}$. A Asociación Galaica enviou circulares a todos os seus asociados, que recibiron tamén a visita nos seus domicilios dunha comisión ad hoc para fomentar a colaboración cos militares rebeldes. A circular, remitida en novembro de 1938, estaba acompañada dun impreso para asinar polo propio destinatario, que debía engadir un donativo. Reprodúcese a continuación o seu contido pola súa relevancia histórica:

20 O Século, n. ${ }^{\circ} 19663,11 / 12 / 1936$, p. 4. Véxase tamén: Diário de Notícias, n. ${ }^{\circ}$ 25457, 18/12/1936, p. 4.

21 O Século, n. ${ }^{\circ} 18692,11 / 01 / 1937$, p. 4.

22 AGA, Exteriores, caixa n. ${ }^{\circ}$ 6639. Carta de José Rodríguez Márquez, da Asociación Galaica de Socorros Mutuos, a Nicolás Franco, 14/11/1938. 


\section{Camarada y Amigo:}

[...] Sabemos que tiene Vd. un alma bien formada. Por eso mismo queremos hablarle al corazón. En España continúa esa guerra, horrible y sangrienta, que estalló el 18 de Julio de 1936. No se trata de una lucha de conquistas materiales ni de ambiciones de partido ni de choque entre dos pueblos. Es España, su Historia, su Fé, su Tradición, la civilización misma de que nuestra Patria es máximo exponente en el mundo contra el comunismo devastador y sanguinario, feroz, vengativo y criminal. Es la verdadera España que lucha por nosotros mismos, por la defensa de la tranquilidad y el orden que disfrutamos y que nos garantiza el trabajo digno de que vivimos rodeados de los nuestros. ¿Y podemos nosotros asistir insensibles al supremo sacrificio de todos aquellos que están dando la misma vida por defendernos del horrible caos comunista? La Causa Nacional de España es nuestra propia Causa. En el triunfo de Franco está nuestro mismo triunfo. ¿Y cómo correspondemos a tan sublime sacrificio? Al menos un recuerdo que patentice nuestra gratitud. Que en las solemnidades de Navidad no falte nuestra expresión de solidaridad y cariño para con nuestros heroicos combatientes! Queremos reuniros en pleito sentimental, enviando a las trincheras de España, los agasajos que simbolicen nuestro aliento a tantísimos héroes que va a pasar la tercera Noche-Buena de guerra, luchando y vigilando por la Civilización! Su nombre, estamos seguros de ello, ocupará honrosamente un lugar de presencia en la lista de «Recuerdos». La comisión que tendrá el honor de visitarle, recogerá el boletín adjunto, que esperamos habrá Vd. llenado, con el donativo que significa su acendrado patriotismo y vivo amor a España!

¡Que Dios le premie y España sea Una, Grande y Libre!

¡Saludo a Franco!

¡Arriba España! ${ }^{23}$

A Asociación Galaica de Socorros Mutuos xa dera mostras da súa firme colaboración coa propaganda franquista en Portugal cando emitiu, o 24 de setembro de 1936, un manifesto contra a implantación en España de ideas e sistemas subversivos de «carácter internacional», en defensa do "patrimonio moral y material»

23 AGA, Exteriores, caixa n. ${ }^{0}$ 6639. Circular anexa á carta de José Rodríguez Márquez a Nicolás Franco, $14 / 11 / 1938$. 
e o respecto da historia, a fe e a memoria dos antepasados. O manifesto rexeita de plano as teorías «bárbaras e utópicas» para impedir o aniquilamento da civilización e, en nome da comunidade inmigrante galega en Portugal, proclama o orgullo de ver a Galicia en poder de Franco, co desexo expreso de que o resto de España fose pronto conquistada polos golpistas:

[...] Pela nossa parte muito honrados nos consideramos manifestando a mais estreita comunhão de ideologia com todos aqueles que só pensam em salvar a Espanha do pior flagelo de todos os tempos. Agora mais do que nunca, e por termos nascido na hispánica região galega, sentimos orgulho pela dignissima posição da nossa terra natal ao contribuir com o maior entusiasmo para a causa sacrossanta e em tudo digna da salvação da Espanha. Estamos de alma, vida e coração ao lado do glorioso Exército espanhol. Desejamos a paz de Espanha. Queremos unha Patria disciplinada, ordenada, consciente, laboriosa, progressiva, forte e nacionalista. E assim há-de ser a Espanha de amanhãa ${ }^{24}$.

Cando o xeneral Franco é nomeado Xefe de Estado, en outubro de 1938, polo goberno de Burgos, a Asociación Galaica de Socorros Mutuos mandoulle un efusivo telegrama de felicitación, que foi publicado en $O$ Século. O telegrama estaba asinado polos membros da xunta directiva, da que formaban parte José Rodríguez Márquez, Benito Pérez Raymundo, Daniel Garrido Oitavén, José Garrido Ventín, Avelino Fernández López, Enrique Fernández Díaz, Enrique Almeida Martínez, Constantino Muñoz Fernández e Carlos Baquero Peruch. Deste xeito, a dirección da asociación demostraba publicamente, unha vez máis, o seu apoio decidido aos militares sediciosos con esta mensaxe: «A Associação Galaica de Lisboa expressa a sua fé inquebrantável no ideal nacionalista Salvador da Espanha nova! Arriba Espanha! ${ }^{25}$. En febreiro de 1937, tras producirse o atentado anarquista contra o goberno de Salazar, os directivos da asociación tamén lle expresan ao ministro do Interior de Portugal a súa «inquebrantable fé» no Estado Novo ${ }^{26}$. Tanto as dúas asociacións galegas referidas como a Cámara Oficial de Comercio e Navegación de España serviron como importantes núcleos de captación de adeptos para o

24 Diário de Notícias, n. ${ }^{o} 25374,24 / 09 / 1936$, p. 4.

25 O Século, n. ${ }^{\circ} 19597,04 / 10 / 1936$, p. 4.

26 AMI-GM/ANTT, M 486, C 40. Carta de Gumersindo Casal Fernández, presidente da xunta directiva da Asociación Galaica de Socorros Mutuos, ao ministro do Interior, 10/02/1937. 
Movemento franquista en Portugal. A través da súa instrumentalización política, a Representación da Junta de Defensa de Burgos puido canalizar de xeito persoal e eficaz a súa propaganda cara aos diferentes sectores que integraban a comunidade inmigrante española.

Por tanto, a diáspora galega en territorio portugués formou parte da estratexia propagandística dos militares insurrectos, que trataron de adoutrinar aos emigrados galegos en Portugal con catro obxectivos principais: recadar fondos económicos para a causa golpista, recrutar combatentes para o campo de batalla, evitar a acción política en defensa da II República e transformar a colonia nunha cómoda retagarda, que ademais prestase apoio loxístico e económico aos militares sediciosos. As institucións da colonia española en Portugal, moitas delas relacionadas coa inmigración galega, serviron así de plataformas de difusión da ideoloxía falanxista e do franquismo, grazas ao determinante apoio que prestou o goberno do Estado Novo aos militares españois insurrectos, que encontraron en Portugal un aliado leal, que proporcionaba cobertura diplomática e colaboraba no aprovisionamento militar ${ }^{27}$.

\section{INTELECTUAIS GALEGOS E PROPAGANDA FRANQUISTA EN PORTUGAL}

A campaña a favor do franquismo en territorio portugués contou coa colaboración de algúns intelectuais galegos, que nalgúns casos asumiron simbólicamente a representación do galeguismo como unha estratexia para conectar e persuadir emocionalmente aos inmigrantes galegos. No marco dunha acción propagandística para outorgar proxección exterior ao movemento fascista español e obter o apoio da colonia galega e española, a utilización de prestixiosas figuras intelectuais de orixe galega por parte dos rebeldes franquistas perseguía tres obxectivos fundamentais: lexitimar políticamente o golpe de Estado en España, elevar o prestixio da causa franquista en Portugal e estreitar os lazos ideolóxicos co salazarismo.

${ }^{27}$ Cf. Pena Rodríguez, Alberto, Galicia, Franco y Salazar. La emigación gallega en Portugal y el intercambio ideológico entre el franquismo y el salazarismo, Vigo, Universidade de Vigo, 1999. 
O Estado Novo de Oliveira Salazar, extremadamente celoso en canto ás actividades políticas dos estranxeiros durante a Guerra Civil española, prohibiu as actividades xornalísticas dos intelectuais demócratas españois en territorio portugués, amedrentados ademais polo temor a seren entregados ao goberno franquista durante a guerra. En ningún caso se podían mostrar partidarios do goberno de Madrid porque iso significaba a expulsión automática de Portugal. A policía política do réxime, a Policía de Vigilância e Defesa do Estado (PVDE), extremou ao máximo as precaucións para evitar calquera tipo de contaxio ideolóxico da España republicana.

Toda a propaganda realizada por membros da colonia española en Portugal estaba supervisada pola Junta de Defensa de Burgos e os seus axentes, que non necesitaron fundar ningunha publicación específica para promover o goberno rebelde español. Porque o franquismo xa era promovido, con grande entusiasmo, polos propios medios de comunicación portugueses, cos que mantiñan un contacto permanente. Os españois residentes en Portugal que non se declararon abertamente a favor dos militares golpistas pasaron a ser sospeitosos, ao igual que os portugueses que non respectaron o statu quo da ditadura salazarista.

As actividades do núcleo franquista da colonia non se concentraban unicamente en pedir donativos por medio das súas festas, poxas, misas ou outras celebracións, organizadas desde a Cámara Oficial de Comercio e Navegación de España, a Asociación Galaica de Socorros Mutuos, o Centro Español, a Mocidade de Galicia ou a Sociedade Española de Beneficencia, entre outros organismos. As súas accións de recadación para o exército franquista ían acompañadas dunha propaganda realizada en español desde a propia prensa portuguesa por intelectuais franquistas, entre os que se atopaban eminentes escritores galegos como Julio Camba, Eugenio Montes, Álvaro de las Casas ou Wenceslao Fernández Flórez. Algúns xornais lusos de referencia, como o Diário de Notícias ou o Comércio do Porto, brindaron as súas páxinas para que os máis ilustres simpatizantes do exército rebelde vencellados a Galicia publicasen artigos a favor do fascismo español ou concedesen entrevistas de propaganda franquista. Entre eles estaban tamén o marqués de Quintanar, Carmen Fernández de Lara, Manuel Falcón, Lasso de la Vega, Francisco Cervantes e moitos outros, que empregaron a súa pluma para promover o franquismo no país veciño. As ideas políticas e sociais da Falange, a concepción franquista da restauración nacional ou a censura sistemática das 
teorías marxistas e o goberno leal á II República son temas recorrentes na propaganda destes intelectuais na prensa portuguesa.

O diario católico $A$ Voz foi un dos diarios no que os intelectuais franquistas adquiriron máis protagonismo, publicando os seus artigos de forma destacada. O Diário de Notícias, o Diário da Manhã, o Comércio do Porto ou as revistas nacionalistas Ocidente, Alma Nacional e Aviz incluíron propaganda en español. $A V o z$, dirixida por Fernando de Souza, foi moi receptiva cos artigos do marqués de Quintanar, que, nunha entrevista concedida ao Diário de Lisboa o 22 de agosto de 1936, vaticinaba un inmediato final da guerra. Entre setembro e novembro de 1936, publicou diversos artigos sobre as consecuencias da guerra para Europa, sobre a necesidade de resucitar a vella alianza peninsular, sobre as virtudes do tradicionalismo español ou sobre o desenvolvemento do enfrontamento bélico, algúns deles lidos nos micrófonos da emisora profranquista Rádio Club Português.

En $A$ Voz atopou tamén espazo xornalístico o escritor español Manuel Falcón, que naquel momento traballaba para o Secretariado de Propaganda Nacional, en colaboración permanente cos representantes franquistas en Lisboa. Durante a guerra, emprendeu unha campaña de prensa ao servizo de Nicolás Franco, de quen recibía instrucións para publicar artigos favorables á rebelión militar en España. Segundo o axente de Burgos Álvaro Seminario, Manuel Falcón era o "cronista de asuntos españois» de $A$ Voz. Neste xornal, demostrou ter unha certa debilidade pola propaganda poética, asinando ata seis poemas, de escasa calidade literaria pero de gran fondo ideolóxico, que plasmaban os seus sentimentos franquistas. Publicou tamén en $A V o z$, en decembro de 1938, unha entrevista co xefe dos Arquivos, Biblioteca e Propiedade Intelectual do goberno rebelde, Lasso de la Vega, quen se atopaba en Portugal para asistir ao doutorado honoris causa do intelectual catalán Eugenio D’Ors pola Universidade de Coimbra. Lasso de la Vega comenta os proxectos que tiña entón o seu Departamento dentro do Ministerio de Educación Nacional. Durante a entrevista, o intelectual franquista, na súa condición de xefe das Lecturas para os Combatentes, solicita publicamente a Falcón que, como axente da «embaixada negra» (a Representación do goberno de Burgos en Lisboa), se ocupe de facer unha campaña de recolleita de libros en portugués para enviarlles aos milleiros de voluntarios portugueses na fronte de batalla. 
Porén os intelectuais profranquistas que tiveron máis eco propagandístico nos medios de comunicación portugueses foron os que estaban vencellados a Galicia. Wenceslao Fernández Flórez foi un dos máis destacados. Presentouse en Portugal como supervivente do «inferno» comunista de Madrid, onde residiu durante o primeiro ano da Guerra Civil, ata que conseguiu pasarse á zona franquista en 1937, segundo a prensa salazarista. Fernández Flórez foi un dos intelectuais fascistas máis populares, activos e eficaces na difusión propagandística do proxecto franquista en Portugal. A súa orixe galega contribuíu de xeito relevante á lexitimación do fascismo diante da colonia galega e da opinión pública portuguesa. Desacreditou o discurso do Partido Galeguista, que pretendía espertar a conciencia e o sentimento de solidariedade da sociedade portuguesa, apelando ás raíces históricas e culturais do nacionalismo galego coa nación portuguesa, como se expón mais adiante.

Wenceslao Fernández Flórez chegou a Lisboa o 24 de maio de 1938. Os lectores do Diário da Manhã (órgano do partido único do réxime, a União Nacional) xa coñecían as súas opinións sobre a guerra porque reproduciu en varias edicións algúns dos seus artigos publicados no $A b c$ de Sevilla, cabeceira en que traballaba desde 1937, logo de conseguir saír «clandestinamente» de Madrid ${ }^{28}$. Na estación do Rossio de Lisboa, nunha recepción de carácter oficial e protocolaria, agardábano Jorge Faria, presidente do Sindicato Nacional dos Jornalistas, e Guilherme Pereira de Carvalho, representante do Secretariado de Propaganda Nacional. Era considerado pola prensa lusa como un dos máis insignes intelectuais españois superviventes ao "xenocidio» do goberno republicano. A súa estadía en Portugal tivo unha enorme repercusión mediática, como correspondía a un ilustre invitado do SPN que ía pronunciar dúas conferencias sobre a «Revolución Nacionalista» ${ }^{29}$.

As intervencións públicas de Fernández Flórez foron retransmitidas en directo pola Emissora Nacional. A primeira alocución do autor español, titulada «O terror vermelho", realizouse o 8 de xuño na sede do propio SPN. No acto estiveron presentes numerosos xornalistas e escritores portugueses. Foi cualificado pola prensa lusa como un éxito rotundo para o SPN e os representantes do goberno de Burgos en Lisboa. A capacidade da sala era insuficiente para acoller a todos

28 Diário da Manhä, n. ${ }^{\circ} 2331,16 / 10 / 1937$, p. 3.

29 Diário da Manhã, n. ${ }^{\circ} 2331,16 / 10 / 1937$, p. 3. 
os asistentes, polo que os organizadores decidiron instalar altofalantes noutras dependencias do edificio. A presentación do intelectual español correu a cargo do director do SPN, António Ferro, que recorda expresamente a campaña de propaganda internacional realizada polos intelectuais portugueses para impedir o fusilamento dos escritores españois en territorio leal. Ferro subliña, ademais, o «erro» cometido por el mesmo en setembro de 1936, cando, no medio da vertixe imparable daquela campaña desde o organismo que el dirixía, se daba por morto a Fernández Flórez. O correspondente do Diário de Notícias Armando Boaventura certificara incluso o seu asasinato publicando unha entrevista póstuma co escritor, na que amosaba a súa admiración por Franco e Salazar ${ }^{30}$. Tendo en conta o sistemático asasinato de intelectuais no bando leal (sic), apuntaba Ferro, a «resurrección» do escritor franquista era un «milagre»:

Flores acabou por conseguir da Espanha vermelha, salvar-se, mas não fácilmente, não como quem parte, com a sua bagagem feita, a horas certas. Salvou-se, para bem de nós todos, para nossa alegria, mas como aqueles raros condenados á morte que conseguem libertarse, quando a noite desce, dum monte de cadáveres que se forma após os fuzilamentos em massa. Conseguiu salvar-se mas deixando nesse monte de cadáveres intelectuais como Ramiro de Maeztu, Manuel Bueno, Salazar Alonso, Muñoz Seca e tantos outros. Testemunha implacável, justiceira, salvou-se para nos vir contar o que os seus olhos viram, o que a sua alma sofreu! [...] Depois da sua conferência todos concluirão que, para a inteligência de Fernandez Flores, homem de bem e escritor de bem, os chamados direitos do homem deixaram de existir, porque os voi (sic) em plena actividade, transmutados em auténticos direitos da fera!. [...] Lembrou em seguida António Ferro que o conferente nasceu na Galiza, provincia de Espanha, mas amiga intima de Portugal, da nossa paisagem, dos nossos costumes, da nossa lingua, circunstancia essa que nos torna Wenceslau Flores particularmente simpático ${ }^{31}$.

A segunda diatriba de Fernández Flórez realizouse o 16 de xuño na Sociedade de Xeografía, cuxa capacidade era moito maior. Esta vez falou sobre «A Mulher na Revolução Espanhola», conferencia publicada integramente polo

30 Diário de Notícias, n. $25353,03 / 09 / 1936$, p. 1.

31 Diário da Manhä, n. ${ }^{\circ}$ 2560, 09/06/1938, p. 4. 
Diário da Manhã e a revista Ocidente. Nesta nova alocución o popular escritor eloxia as sobresaíntes calidades da muller falanxista fronte aos «salvaxes» costumes das mulleres marxistas ${ }^{32}$. A primeira, segundo o seu argumento, é unha boa nai e tenra co seu marido, mentres a segunda, cuxos modelos representaban a Pasionaria ou Margarita Nelken, é un auténtico monstro que perdeu os valores máis «puros» do seu sexo ${ }^{33}$. A xeira do escritor de $O$ bosque animado continuou en Porto. Alí foi recibido o 21 de xuño entre aplausos de diplomáticos e intelectuais portugueses no Salão Nobre do Centro Comercial, durante unha sesión presidida polo alcalde da cidade, Mendes Correia, xunto aos escritores Alberto Pinheiro Torres e Augusto Pires de Lima ${ }^{34}$.

A campaña propagandística de Fernández Flórez tivo tamén unha vertente xornalística e editorial. Durante o verán de 1938, escribiu para o Diário de Notícias unha soada serie de 15 crónicas sobre as súas peripecias persoais para fuxir do inferno madrileño e salvar a súa vida logo de iniciada a guerra, grazas á axuda prestada polo embaixador portugués, Riba Tâmega. O seu traballo xornalístico foi recollido nun libro de propaganda anticomunista editado ese mesmo ano pola Empresa Nacional de Publicidade, propietaria do Diário de Notícias, titulado $O$ terror vermelho ${ }^{35}$. A cuberta deste opúsculo aparece ilustrada cun cadro que mostra unha caveira adornada cunha gorra vermella que loce unha estrela comunista. O libro foi traducido a varias linguas e difundido internacionalmente ao mesmo tempo que a edición portuguesa ${ }^{36}$. No prólogo, W. Fernández Flórez expresa o seu desexo de convencer os lectores de evitar o "contaxio» do comunismo ruso, que segundo el se estendeu rapidamente polo territorio español logo de facerse co goberno os burgueses que simpatizaban coas ideas marxistas: «As ideias eram russas, os processos eram russos; russos eram os homens chegados para dirixir até as matanças; russas as armas, russas as conservas que, ao princípio, deram ao povo, russos os nomes que se invocavam, russas as brigadas, os originais dos grandes retratos que presidiam os comícios e as deliberaçōes» ${ }^{37}$. Esta supos-

32 Ocidente, vol. I, n.o 3, xullo de 1938, pp. 419-430; vol. II, n. ${ }^{\circ} 4$, agosto de 1938, pp. 79-81.

33 Diário da Manhä, n. ${ }^{\circ} 2508,17 / 06 / 1938$, p. 5.

34 Ídem, n. ${ }^{\circ} 2573,22 / 06 / 1938$, p. 8.

35 Fernández Flórez, Wenceslao, O terror vermelho, Lisboa, Empresa Nacional de Publicidade, 1938.

36 Ídem, (s.p.), (pp. 2 e 3).

37 Ídem, (s.p.) (p. 12). 
ta invasión vermella, segundo o autor, foi estimulada por «falsos» intelectuais e xornalistas «de meia tegela» que se enriqueceron facendo propaganda comunista. E engade que aqueles «seudo-intelectuais» fuxiron arrepentidos da súa incendiaria provocación, que sumiu a España no horror ${ }^{38}$. O escritor galego, ademais, móstrase orgulloso dos resultados da propaganda realizada en Portugal. Segundo escribe, dous rapaces portugueses agradecéronlle persoalmente, nunha das súas conferencias, os seus artigos xornalísticos porque estes «tinham estrangulado nos seus espiritos uma tendencia de simpatia, de aproximação para o comunismo» ${ }^{39}$.

Xunto a Fernández Flórez, houbo outros intelectuais galegos que asumiron tamén un certo protagonismo público nos medios de comunicación portugueses para xustificar diante da opinión pública lusa a acción represiva do exército de Franco en Galicia e España. O escritor vigués Eugenio Montes, nomeado director do Instituto Español de Lisboa polos representantes do goberno de Burgos, pronunciou unha palestra sobre as causas da guerra no Teatro da Trindade de Lisboa, o 14 de maio de 1937, á vez que publicaba un artigo no Diário da Manhã titulado «De Dostoievski a Estaline» ${ }^{40}$. A súa presentación no Teatro da Trindade foi realizada por Manuel Múrias, simpatizante da causa facciosa e director da revista Ocidente ${ }^{41}$. Mentres, en Porto, o escritor Julio Camba e o profesor da Universidade de Santiago de Compostela Álvaro de las Casas erixíronse en voceiros oficiais da «verdade» franquista. De las Casas, que fora militante do Partido Galeguista e fundador da Vangarda Nazionalista Galega, estableceuse naquela cidade en setembro de 1936, despois dunha estadía en Alemaña e Italia. Mantiña unha estreita relación co Comércio do Porto, que se mostrou durante a guerra interesado en publicar asuntos relacionados coa colonia española naquela cidade e, de modo moi especial, sobre todo o relacionado con Galicia ou o galeguismo.

Sobre a política do franquismo en Galicia, suscitáronse críticas entre algúns sectores da sociedade portuguesa pola represión rebelde cos nacionalistas galegos, que se difundiron a través da circulación clandestina de follas voantes, folletos e periódicos distribuídos por organizacións anarquistas e pola Frente Popular Portuguesa. Para desacreditar esa propaganda opositora no norte de Portugal, o

\footnotetext{
38 Idem, (s.p.) (p. 11).

39 Ídem, (s.p.) (p. 18).

40 Diário da Manhã, n. ${ }^{\circ} 2177,14 / 05 / 1937$, pp. 3 e 7.

41 O Século, n. ${ }^{\circ} 19813,15 / 05 / 1937$, p. 6.
} 
fascismo ibérico utilizou, sobre todo, o relato favorable ao franquismo do escritor galeguista Álvaro de las Casas. O que fora autor de obras como Teatro dos nenos ou Rechouchio, concedeu unha entrevista o 7 de setembro de 1936 que foi portada do Comércio do Porto. O antetítulo do diálogo xornalístico co intelectual galeguista era "A Galiza na revolução espanhola» e o título: "O depoimento dum galeguista: Pela Civilização e pela Espanha contra a demência tartárica! ${ }^{42}$. Álvaro de las Casas é tratado como portavoz do nacionalismo galego, e como tal manifesta a posición deste movemento ante o conflito. O Comércio do Porto contextualiza a entrevista sinalando que non deben ser confundidos os nacionalistas galegos, defensores da unidade de España, co separatismo vasco e catalán:

[...] a Galiza formou, desde os primeiros momentos, um bloco sólido e homogéneo ao lado do exército espanhol, mais nem por isso deixava de ser curioso pescudar da maneira como algumas figuras representativas da inteligência galega entendem a solidariedade dada pela unanimidade da populaçãou do Noroeste hispânico ao movimento de reconstrução espanhola, desencadeado pelo Exército do país vizinho ${ }^{43}$.

Segundo a versión ofrecida polo Comércio do Porto, Galicia era unha rexión que apoiaba incondicionalmente ao exército rebelde. Na entrevista, Álvaro de las Casas, cun discurso de ton imperialista, consideraba que as tropas de Franco estaban «salvando as mais puras essências de "europeidade" e todos os valores morais que deram á Espanha um pôsto de primeira ordem no diálogo das mais antigas, nobres e gloriosas civilizaçôes» ${ }^{44}$. Porén, na súa argumentación política, o intelectual galego recoñece as especificidades de Galicia como «individualidade» histórica e, ao mesmo tempo, afirma que a rexión galaica necesitaba un «robustecimento» da súa personalidade hispánica. «Neste instante, a minha terra de novo com perfeita unanimidade, com ardor insuperável, com a fé dun verdadeiro misticismo, tôda ela unida num apertado feixe, está em armas pela salvação e pela restauração da Espanha, pelo prestixio da Europa ${ }^{45}$. O testemuño de Álvaro de las Casas é utilizado polo Comércio do Porto para concluír con rotundidade que o movemento galeguista era franquista:

42 Comércio do Porto, n. ${ }^{o} 233,07 / 09 / 1936$, p. 1.

43 Ídem, p. 2.

44 Ibidem.

45 Ibidem. 
«Nenhum equivoco é mais possível. O galeguismo declarou-pélase Civilização, pela Espanha e pelo Exército nacionalista. Proclamou-ou abertamente, um dous mais nobres e lúcidos espíritos da terra galega ${ }^{46}$.

O 18 de setembro de 1936, Álvaro de las Casas participou como representante do Movemento Nacional español no multitudinario mitin anticomunista que tivo lugar en Porto. E o 12 de outubro seguinte foi o conferenciante invitado nunha das moitas sesións de propaganda organizadas pola União Nacional. Pronunciou o seu discurso xunto ao coronel Namorado de Aguiar, comandante da Polícia de Segurança Pública e da Legião Portuguesa, e Vasco Mourão, presidente da comisión política da União Nacional. Pouco despois, volveu a ter a oportunidade de lanzar desde o Comércio do Porto unha «vibrante exortação» aos nacionalistas portugueses, aos que lles comunica a chegada do "grande dia de Europa» contra a ideoloxía materialista e o islamismo:

Como em tempos passados contra o perigo islâmico, que ameaçava arrasar os fertilíssimos campos dos velhos impérios, os povos que, hoje, têm consciência de si e renegam nefandas claudicações servís, juntam-se, outra vez, para salvar os eternos valores morais, reverdecer os sempre viçosos loiros das nossas histórias gloriosas e reafirmar a soberana hegemonia do espirito. Espanha é, outra vez, trincheira e clarim da Europa. [...] Estamos em luta titânica entre as duas mais opostas concepçôes do mundo. A um internacionalismo utópico e absurdo opomos o perfil nitido das nossas nacionalidades, ao nomadismo judaico e depauperado opomos a mais firme posse do solo pátrio, ao ateísmo brutal o princípio religioso, ao conceito materialista da vida a nossa sêde inesgotável de infinito, à luta de classes criminosa e esgotante a mais firme coesão no Estado, por que todos, ricos e pobres, patrôes e trabalhadores, somos parte essencial de um todo indivisível, somos carne e potência de um corpo e alma únicos; em suma: somos, conjuntamente História e Futuro ${ }^{47}$.

Álvaro de las Casas converteuse en asesor do Comércio do Porto para asuntos relacionados con Galicia e España. O 7 de outubro de 1936, coordinou a entrevista realizada ao avogado e publicitario galego José Ignacio Ramos, en calidade de cofundador das Juntas de Ofensiva Nacional Sindicalista. Ramos é descrito

\footnotetext{
46 Ibidem.

47 Ibidem.
} 
como outro supervivente do «inferno madrileno», cuxo soño era ser un dos primeiros falanxistas en entrar na capital española. O tamén galego Julio Camba foi convidado por Álvaro de las Casas para dirixirse ao pobo portugués desde a tribuna informativa do Comércio do Porto. O autor de Aventuras dunha peseta tratou de demostrar que «tudo quanto há de categorizado na vida espanhola está ao lado do exército contra a invasão comunista ${ }^{48}$. Camba falou da posición adoptada polos intelectuais españois diante do golpe militar. Mentres o goberno de Madrid fomenta o asasinato de escritores, artistas e científicos, apunta Camba, á beira dos franquistas están personaxes como: Unamuno, Eugenio Montes, Pío Baroja, Luca de Tena, José María Pemán, García Lorca (sic), Bergamín, Sánchez Mazas, Salaverría, Pujol, Otero Pedrayo ou Giménez Cabaleiro. Julio Camba renegou do manifesto antifranquista que asinara en apoio ao goberno de Madrid, no que estampou a súa sinatura, dicía, baixo ameazas. A súa postura era radicalmente clara e fascista: «Ao lado do exército, ate onde seja necessário. Como homem sou anti-comunista e, como espanhol, desejo uma limpeza que faça desaparecer, de vez, tôda êssa turba de patifes que, por infelicidade, nos tinha caido em cima; é precisso fazer uma nossa Espanha. Chegou a hora ${ }^{49}$.

\section{CASTELAO E O PARTIDO GALEGUISTA, CONTRA O FASCISMO IBÉRICO}

Dous dos intelectuais e políticos máis representativos da causa galeguista, Alfonso Rodríguez Castelao e Ramón Suárez Picallo, deputados do Partido Galeguista nas Cortes da II República cando se iniciou a guerra, fixeron unha campaña contra o Estado Novo portugués a través da publicación e difusión dunha carta-manifesto. Nela acusaron publicamente a Salazar de ser o verdugo da cultura e da identidade do pobo galego. A carta-manifesto asinada polos deputados galegos foi editada e impresa en Madrid con formato de folleto, en abril de 1937, pola Delegação em Espanha da Frente Popular Portuguesa, e foi reproducida na prensa afín ao

48 Comércio do Porto, n. ${ }^{\circ}$ 262, 07/10/1936, p. 1. Antetítulo: "Como pensa a intelectualidade espanhola». Título: «D. Julio Camba, o ilustre escritor fez importantes declaraçōes a "O Comércio do Porto"».

49 Ibidem. 
goberno republicano. O título deste texto propagandístico era Carta a Oliveira Salazar, ditador de Portugal ${ }^{50}$.

O manifesto foi distribuído clandestinamente en territorio portugués para mobilizar a sociedade lusa en defensa dos seus «irmáns» galegos. O seu contido, ademais, tivo resonancia na prensa ibérica da época. Algunhas cabeceiras portuguesas e españolas enfrontáronse polo contido do folleto, cuxa difusión foi prohibida e perseguida pola policía política lusa, que sospeitaba que o texto fora introducido clandestinamente no seu territorio por medio do correo enviado desde Francia.

O texto acusaba a Salazar de traizón. Segundo Castelao e Suárez Picallo, o ditador portugués estaba cavando a tumba do galeguismo: «Sabe V. que o triunfo do feixismo em Hespanha supón a volta de Catalunya, Euzkadi e Galicia á tiranía centralista - tiranía que Portugal non soportou —. Cré V., señor dictador, que Portugal pode diñamente axudar aos militares hespañoes no afán de abolir as autonomías?», sinálase no escrito. Salazar é acusado tamén de cómplice do asasinato de centos de galegos. Os deputados nacionalistas, empregando unha singular dureza co ditador luso, acúsano de fechar as fronteiras con Galicia para impedir o refuxio en Portugal dos demócratas que fuxían da represión fascista. Segundo o folleto, Salazar permitiu a morte de moitos galegos, malia os lazos eternos que unían a comunidade galaica con Portugal:

Galiza e Portugal forman, étnicamente un mesmo pobo. Fórono no abrente da Hestoria e camiñaron xuntos moito tempo, a falar e cantar no mesmo idioma. Xuntos erguemos un dos mais belidos momentos do mundo: a gran poesía lírica dos cancioneiros galaico-portugueses. Xuntos creamos unha cultura e un xeito de vida. E o rio Miño era o noso pai. Sabe V. que ainda dispois da malfadada separación Galiza e Portugal queríanse como dous namorados. [...] Debe saber V. que o noso amor a Portugal valeunos a xenreira dos «nacionalistas hespañoes» e que foi xustamente ese amor o delito mais grave que se nos imputa. ¿Cré V., señor Oliveira Salazar, que os galeguistas estábamos infectados dalgunha enfermedade perigosa para o pobo portugués?. Pois V. tratounos como apestados, metendo galeguistas en cadeas inmundas ou entregándoos aos asesiños

50 Castelao, Alfonso e Suárez Picallo, Ramón, Carta a Oliveira Salazar, ditador de Portugal, Madrid, Delegação em Espanha da Frente Popular Portuguesa, 1937. 
de «Falange Española». Sabe V. que os intelectuales portugueses e galegos comezaban a formar unha comunidade cultural que sería outro expoñente da nosa estirpe atlántica. Chamabámonos irmáns, e Rosalía de Castro era o "corpo santo da Saudade». Un poeta, amigo de V., quixo engaiolar a Galiza con este chamamento: "Deixa Castela e ven a nós!». Sabe V. que os galeguistas fechábamos os ouvidos a todo chamamento ilícito; pero queríamos ser fideles aos legados da tradición e cada vez sentíamonos mais empurrados cara Portugal [...] Pois ben, señor Oliveira Salazar: V. matou as nosas ilusións. ¿Cré V. que se pode axudar descaradamente aos imperialistas hespañoes?51.

Mentres Castelao e Picallo denunciaban a situación dos fuxidos galegos en territorio portugués, un grupo de refuxiados clandestinos en Portugal envíalle unha carta a Oliveira Salazar, con carácter particular, solicitando que puxese fin á persecución dos galegos que entraron en Portugal fuxindo do fascismo e que sexa clemente coa súa situación:

[...] Nosotros, humildes gentes de Galicia — víctimas siempre, ahora como antes, con izquierdas y con derechas del caciquismo gallego — somos ajenos a las causas diplomáticas que motivaron el rompimiento de relaciones entre ambos paises hermanos. [...] Porque es inhumano, que a nosotros, respetuosos con la política de Portugal, que buscamos la protección de sus leyes, se nos obligue a llevar una vida absolutamente indigna. Es inhumano que se nos persiga a tiros en los pueblos y montes (tenemos testimonios). Es inhumano, Excelentísimo señor, que cuando somos detenidos se nos entregue a los nacionalistas españoles [...]. No pretendemos en modo alguno burlar las leyes de Portugal, ni tampoco forzar su hostilidad. Si su Excelencia juzga que somos agentes peligrosos de propaganda política, razón por la cual no podemos residir en esta nación hermana, autorícenos el embarque libremente para otros países, o reclúyanos en un campo de concentración, con gastos de sostenimiento por nuestra cuenta. Si no podemos vivir en Portugal, déjenos su excelencia libertad para abandonarlo. Es cuanto respetuosamente le pedimos $[\ldots]^{52}$.

51 Ibidem, pp. 6 e 7.

52 AOS/ANTT, CO/NE-9I, carpeta 1, 7a subdivisión, follas no 18-19. Carta enviada por un grupo de refugiados gallegos a Oliveira Salazar, 19/09/1937. 
Galicia foi a primeira rexión veciña de Portugal en quedar baixo control dos insurrectos. Esta circunstancia provocou unha avalancha de refuxiados. Os galegos que conseguiron cruzar a fronteira atravesando o Miño ou a serra de Castro Laboreiro atoparon en Portugal un ambiente solidario nas aldeas portuguesas. Pero as autoridades locais eran totalmente hostís. Os refuxiados foron perseguidos a tiros polos montes e moitos deles entregados pola policía portuguesa aos rebeldes españois. Varios centenares de fuxidos sobreviviron clandestinamente practicando o contrabando durante a Guerra Civil, mentres esperaban aforrar para ter a oportunidade de chegar ata algún porto e embarcar con destino a América.

O texto ía precedido por unha introdución asinada pola delegación en España da Frente Popular Portuguesa. Nel descríbese o perfil biográfico dos autores do manifesto, que pretenden representar a solidariedade do nacionalismo galego co pobo portugués fronte ao salazarismo: «Aos dois nobres signatários desta carta não temos a dizer senão que o povo Portugués, revoltado ate a náusea, anseia pela hora de resgatar a sua Pátria do crime monstruoso e sem par com que o Ditador a infamou», conclúe o prefacio. Na carta-manifesto tamén se acusa ao ditador portugués de poñer en risco a propia independencia de Portugal, resaltando os sacrificios realizados polo pobo portugués para manter en pé a fronteira con Castela. Os deputados galegos argumentaban que a única garantía para a integridade territorial de Portugal era unha España organizada en autonomías:

[...] Non cabe dúvida de que foi Portugal quen rompeu a unidade hispánica. E fixo ben. Agora, señor profesor de Dereito: Sabe V. que o "motivo patriótico» que invocan os militares hespañoles, para xustificaren o seu crime, foi provocado pola xenerosidade constitucional, pois, según eles, a concesión das autonomías pon en perigo a «sagrada unidad de la patria» cando, en verdade sirve para fortificala. Sabe V. que os militares facciosos defenden, somentes, un sistema — o sistema unitario e centralista — que causou a perda do noso imperio colonial e a deseintegración peninsular. Sabe V. que eses militares desprezan olímpicamente a Portugal, sen coñecelo, e gardan nos seus adentros, un anceio irreprimible de reconquistalo; entrementras que os pobos autónomos da República hespañola serían sempre unha garantía da independencia de Portugal $[\ldots]^{53}$.

53 Ídem, p. 6. 


\section{CONCLUSIÓNS}

O fascismo español estableceu unha estreita colaboración co salazarismo durante a Guerra Civil española co obxectivo de consolidar, tanto en España como en Portugal, os seus respectivos proxectos autoritarios. A ditadura portuguesa, por medio do seu aparello de propaganda e de todas as súas estruturas mediáticas, lexitimou o Movemento Nacional franquista fomentando unha intensa campaña contra o goberno da II República. A propaganda estivo especialmente protagonizada por intelectuais de orixe galega que contribuíron a desacreditar o galeguismo democrático, cuxa influencia sobre a colonia galega en Portugal e a sociedade portuguesa foi unha das principais preocupacións do franquismo e do salazarismo. Neste contexto, a maioritaria colonia galega en Portugal foi obxecto de campañas de propaganda para recadar donativos ou recrutar soldados para o bando franquista. Varias das principais institucións asociativas da comunidade inmigrante galega, como a Asociación Galaica de Socorros Mutuos ou La Juventud de Galicia colaboraron coa acción política do fascismo español en Portugal.

Intelectuais galegos de prestixio como Wenceslao Fernández Flórez, Álvaro de las Casas ou Eugenio Montes convertéronse en portavoces da causa franquista en Portugal, mentres os verdadeiros representantes do galeguismo tentaban sen éxito facer chegar á opinión pública lusa o seu discurso político sobre o movemento fascista ibérico e os graves prexuízos para Portugal e Galicia. Os intelectuais franquistas tiñan á súa disposición todas as tribunas informativas de Portugal para facer a súa propaganda. Porén, os representantes do Partido Galeguista nas Cortes españolas, Alfonso Rodríguez Castelao e Ramón Suárez Picallo, tiveron moitas limitacións para difundir as súas ideas. Unha das iniciativas máis interesantes dos políticos galeguistas contra a ditadura foi o manifesto Carta a Oliveira Salazar, ditador de Portugal, editado pola delegación da Frente Popular Portuguesa en Madrid, que foi introducido e difundido clandestinamente en territorio portugués. 